УДК 004.239:719

DOI: 10.31866/2617-796x.2.2.2019.187727

\title{
Баркова Ольга,
}

старший науковий співробітник, кандидат технічних наук, заступник голови технічного комітету стандартизації

TК 144 «Інформація і документація», Державна науково-педагогічна бібліотека України

імені В. О. Сухомлинського, експерт УКФ,

Київ, Україна

olgabarkova@gmail.com

https://orcid.org/0000-0003-4412-1835

\section{Бабенко Володимир,}

кандидат технічних наук, дочент,

Науково-дослідний, проектно-конструкторський

та технологічний інститут мікрографії,

Харків, Україна

kripppon@gmail.com

https://orcid.org/0000-0003-0006-3362

\section{Савич Андрій,}

молодший науковий співробітник, кандидат технічних наук, доцент,

Науково-дослідний, проектно-конструкторський

та технологічний інститут мікрографії,

Харків, Україна

andysav@rambler.ru

https://orcid.org/0000-0003-0590-9195

\section{ПРОГРАМНЕ ЗАБЕЗПЕЧЕННЯ ЦИФРОВІЗАЦІЇ УСТАНОВ ПАМ'ЯТІ: ПРОБЛЕМИ І ПІДХОДИ У ВІТЧИЗНЯНОМУ СЕКТОРІ СПАДЩИНИ}

Мета дослідження - розробити рекомендації щодо розвитку програмного забезпечення установ пам'яті відповідно до цифровізації культурної спадщини.

Методи дослідження. На основі емпіричних досліджень й аналізу стану програмно-технологічного забезпечення вітчизняних установ пам'яті здійснено огляд підходів до розробки програмних продуктів у секторі історико-культурної спадщини. Проведено аналіз повільного впровадження програмного забезпечення у вітчизняних установах пам'яті, що негативно впливає на процеси цифровізації, зокрема на розвиток інформаційних ресурсів і цифрових колекцій, електронний облік фондів. Визначено основні підходи до забезпечення інформаційних виробництв програмними засобами та організації ефективної взаємодії суб'єктів життєвого циклу програмного забезпечення.

Наукова новизна полягає в запропонуванні для вітчизняних установ пам'яті ефективного напряму проєктного менеджменту програмно-технологічних розробок від формуван-

(C) Баркова О. В.

(C) Бабенко В. В.

(C) Савич А. А. 
ня технічного завдання до його впровадження. Надано рекомендації щодо забезпечення якості інтерфейсів та веб-сайтів цифрових ресурсів та онлайн-сервісів установ пам'яті.

Висновки. Застосування наведених результатів досліджень сприятиме підвищенню якості ресурсів і сервісів у вітчизняному секторі культурної спадщини, доступності цифрових ресурсів і сервісів широкій аудиторії користувачів. Це сприятиме цифровому розвитку та інтеграції національної культурної спадщини в глобальні інформаційні системи та інтегровані цифрові ресурси, збільшенню долі вітчизняного контенту у світовому історико-культурному ресурсі та формуванню позитивного іміджу України як частини європейської і світової історії та сучасного ІТ-суб'єкта в секторі культурної спадщини. Матеріал розраховано на керівників та фахівців установ пам'яті, студентів та IT-фахівців, орієнтованих на цифровізацію спадщини та креативні індустрії.

Ключові слова: установи пам'яті; культурна спадщина; цифровізація; життєвий цикл програмного продукту; програмне забезпечення; інформаційні технології; оцифровування.

Вступ. Незважаючи на значний світовий попит на українських розробників програмних продуктів, в Україні ринку програмного забезпечення в секторі культурної спадщини практично немає. Це обумовлює значне відставання в цифровізації вітчизняних установ пам'яті (бібліотек, музеїв, архівів тощо) та унеможливлює інтеграцію їхніх колекцій у глобальні історико-культурні ресурси та системи. У бібліотеках (за винятком автоматизованих систем для електронних каталогів), у більшості музеїв та архівів практично відсутні вітчизняні програмно-технологічні рішення автоматизації інформаційних процесів, обліку фондів, комплексні та інтегровані технології оцифровування, а також системи онлайн-репрезентації оцифрованої спадщини та обслуговування користувачів, а рівень сучасності, інформативності, привабливості та актуальності наявних, на жаль, не витримує порівняння з провідними світовими зразками. Вебсайти установ пам'яті здебільшого не оперують динамічними даними та нагадують стінгазети й оголошення, перенесені в онлайн. У вітчизняному секторі культурної спадщини досі практично немає зведених електронних ресурсів національного та міжнародного значення, відсутні багатомовні ресурси.

Варто зазначити, що впродовж останніх років завдяки активізації грантової діяльності в секторі культурної спадщини з'явилися окремі яскраві програмні рішення та веброзробки для цифрових колекцій з 3D цифрового репрезентування і мобільних застосувань. Вони вивели в онлайн низку цікавих цифрових продуктів і надали доступ до розширеної інформації про історико-культурні експозиції національної культурної спадщини. Ці сучасні цифрові та технологічні рішення оживлюють інтерес до історико-культурних зібрань та самих експозицій. Проте не вирішеними залишаються системні проблеми, пов'язані з відсутністю типових інтегрованих рішень з автоматизації інформаційних процесів та онлайн-презентації цифрових ресурсів спадщини.

Результати дослідження. Дослідження стану впровадження програмного забезпечення у вітчизняних установах пам'яті здійснювалося авторами на платформі заходів «Оцифроване надбання: збереження, доступ, репрезентація», що проводилися у 2013-2018 роках, під час професійного спілкування та спільної реалізації IT-проєктів з учасниками цих заходів. Результатом є, по-перше, вияв- 
лення фактичної відсутності комплексного і системного підходу до автоматизації та цифровізації в установах пам'яті. Такий стан обумовлено відсутністю міжсекторальних та міждисциплінарних знань з предметної галузі спадщини в розробників та базових IT-знань, розуміння ринку програмних продуктів і розробок, а також уявлень про можливості сучасних програмних продуктів - у представників відомств та установ сектору спадщини. Брак цифрових навичок у фахівців установ пам'яті зумовлює ще й ментальний чинник цифрового гальмування - стійкі застаріли підходи до роботи та неготовність повноцінно використовувати навіть уведені рішення, що робить впровадження малоефективними і спричиняє негативний вплив на інтерес розробників.

По-друге, в Україні поки що не існує типових рішень для установ пам'яті. Проте $€$ окремі розробки систем і технологій, які можна застосовувати через придбання готових програмних рішень, аутсорсингу та інформаційних сервісів (наприклад, оцифровування, обробка контенту, формування метаданих), а також розвивати в ході науково-технічної співпраці з розробниками та зі стартапами.

Протягом історії розвитку інформаційно-програмних рішень у секторі спадщини було визначено декілька підходів та моделей взаємодії суб'єктів процесу розробки та впровадження програмного забезпечення (ПЗ).

1. Реалізація завдань з розробок та впровадження ПЗ за допомогою наявного штату установи пам'яті.

Переваги: не потребує додаткових фінансових витрат (за винятком можливого розширення штату висококваліфікованими IT-фахівцями).

Недоліки: вимагає докладних досліджень, тривалого часу реалізації, не гарантує швидкого та якісного результату.

2. Замовлення потрібних програмних рішень у потужних IT-інтеграторів.

Переваги: гарантована якість суто програмного рішення.

Недоліки: потребує значних фінансових витрат і тривалого часу на докладні дослідження виконавцем предметної галузі спадщини.

3. Пошук і придбання західних закордонних системно-технологічних рішень.

Переваги: гарантована якість замовлених рішень.

Недоліки: витрати часу на пошук, порівняння; значні фінансові витрати на придбання, супроводження і підтримку; необхідність мовної локалізації інтерфейсів.

4. Використання програмних рішень відкритого коду і вільно-доступних рішень.

Переваги: не потребує коштів на придбання.

Недоліки: аналогічні пункту 1, обмежений/типовий функціонал та інтерфейс, необхідність мовної локалізації, потребують участі ІТ-фахівців.

5. Співпраця з вітчизняними розробниками, придбання базових та постзамовлення окремих рішень, сумісні дослідження і впровадження.

Переваги: помірні фінансові витрати, швидке впровадження готових рішень, запланований результат визначеної якості, поєднання індивідуальних вимог і типових рішень, послідовний розвиток.

Недоліки: немає. 
Доцільним є останній варіант. Наприклад, розробники програмних рішень у змозі забезпечити розробку та впровадження необхідних базових програмно-технологічних завдань, визначених разом з установою пам'яті, та відповідно їх ефективний старт і подальшу підтримку. Надалі проєктна співпраця дозволить нарощувати функціонал та масштабувати систему, розробляти потрібні інтерфейси в обраному дизайні-усе це в запланованому режимі ресурсних та фінансових витрат.

Однак слід пам'ятати, що якісне та/або швидке виконання програмно-технологічних завдань залежить від двох умов: 1) вимагатиме роботу груп висококваліфікованих розробників різного профілю та інших IT-фахівців; 2) сама система не працює, потрібна організація інформаційного виробництва. У будь-якому разі на штат фахівців установи пам'яті покладено завдання фахової експлуатації впроваджених рішень і створення контенту - інформаційних ресурсів установи, а також здійснення наукових досліджень самостійно або з ІТ-фахівцями та розробниками ПЗ щодо їх розвитку відповідно до світових тенденцій і стандартів.

Ефективна взаємодія суб'єктів розроблення ПЗ вимагає певного взаєморозуміння предмета й умов розробки, упровадження та підтримки.

Замовникам від спадщини треба враховувати сталі правила ринку ПЗ, зокрема щодо ліцензійного розповсюдження ПЗ, умови гарантованого та взаємні обов'язки постгарантованого супроводження, умови оновлення версій.

3 метою запобігання поширених хибних уявлень щодо ПЗ установи пам'яті зроблено загальні нотатки щодо вимог та умов упровадження і розвитку інформаційної системи (IC) установи пам'яті, які слід враховувати як замовникам від спадщини, так і розробникам.

Функціональний склад IC, орієнтований як на окремі об'єкти, так і на колекції об'єктів, забезпечує:

- технології обліку, опрацювання, керування, онлайнової репрезентації та сервісів;

- аутентифікацію користувачів і персоналізацію користування;

- уніфікацію відповідно до стандартів, форматів та інших вимог сфери застосування;

- інтеграцію з іншими ресурсами;

- інтероперабельність з іншими системами.

Система вебінтерфейсів, унікальний дизайн установи

Ресурсний склад IC вміщує:

- базу метаданих (адміністративні, облікові, описові, пошукові та інші метадані);

- файлове сховище (майстер-копії, копії для користування, документи, документація тощо);

- пов'язані зовнішні для IC ресурси (зокрема, хмарні сховища).

Адміністрування і доступ:

- ролеве керування і доступ;

- статистика ресурсів, відвідувань.

Комплексна система захисту інформації (КСЗІ) - взаємопов'язана сукупність організаційних та інженерно-технічних заходів, засобів і методів захисту інформації. 
Сучасна інформаційна система не може бути закінченою. Вона розвивається версійно, масштабується та функціонально розширюється, може позиціонуватися як складова «родини систем» - відповідно до світових тенденцій розвитку інформаційних і цифрових технологій, відповідних нормативів та потреб інформаційного суспільства.

Ефективне впровадження і функціонування IC потребує певної матеріальної бази та комплексу різних видів забезпечення: інженерного, технічного, технологічного, кадрового, нормативного, інформаційного, правового, лінгвістичного тощо.

Потенційними проблемами впровадження будь-якої нової системи завжди будуть: інертність, психологічний супротив, брак знань і кваліфікацій. Ефективність упровадження залежить від менеджменту.

Необхідно зазначити, що взаємні непорозуміння між розробниками програмних продуктів та установами пам'яті (споживачами цих продуктів) виникають як на етапах складання технічного завдання (технічне завдання (Т3) - документ, оформлений в установленому порядку, який визначає мету, підстави, призначення, вимоги, які необхідні для розроблення, розвитку або модернізації програмного продукту або програмного забезпечення ITC, а також стадії та етапи розробки), так і супроводження й підтримки після впровадження. Наприклад, розроблення ТЗ на засіб автоматизації інформаційних процесів або вебпродуктів сьогодні викликає запитання і спричиняє складності написання для обох сторін, суб'єктів програмних розробок (як для культурних інституцій (замовників), так і для IT-розробників саме щодо запитів сектору спадщини), про причини чого йшлося вище.

На нашу думку, ефективна взаємодія замовника і розробника програмного забезпечення та зниження ризиків замовника $є$ необхідною умовою для реалізації системного підходу до автоматизації інформаційних процесів та запорукою успіху цифровізації установ пам'яті.

Під ефективною взаємодією слід розуміти своєчасну та повну реалізацію вимог замовника до функціональних можливостей розроблюваного програмного забезпечення, за якої ризики замовника зведені до мінімуму.

Ризики - це ситуації або можливі події, які можуть спричинити до того, що проєкт зазнає невдачі в досягненні своїх цілей. У роботі (Boehm, 1986) сформульовано найбільш поширені ризики в послідовності за пріоритетами:

- дефіцит фахівців;

- нереальні строки та бюджет;

- реалізація невідповідної функціональності;

- розробка неправильного інтерфейсу користувача;

- загострене прагнення до досконалості, непотрібна оптимізація і відточування деталей;

- безперервний потік змін;

- брак інформації про зовнішні компоненти, що визначають оточення системи або залучених в інтеграцію;

- недоліки в роботах, які виконують із залученням зовнішніх (щодо проєкту) ресурсів; 
- недостатня продуктивність одержуваного П3;

- суттєва відмінність кваліфікації фахівців різних галузей знань.

Ефективність розробляння ПЗ значною мірою залежить від обраної та реалізованої моделі його життєвого циклу (далі - ЖЦ) (Чумакова, 2009; Бахтизин, 2006).

ЖЦ ПЗ та систем (Бахтизин, 2006) - це сукупність процесів, робіт та завдань, що охоплює розробку, експлуатацію та супроводження ПЗ і систем, починаючи з аналізу їхньої концепції або потреби в замовленні до припинення їхнього використання. Під системою розуміють комплекс, що складається з процесів, технічних і програмних засобів, пристроїв та персоналу, який володіє можливістю задовольняти встановлені вимоги або цілі (ДСТУ ISO/IEC/IEEE 12207:2018, 2018).

Спіральна модель ЖЦ (рис. 1) відображає базову концепцію, яка полягає в тому, що передбачено розробку ПЗ під час використання методу прототипування, де прототип - це робоча модель, яка зазвичай має лише частину потрібних можливостей та не забезпечує всієї функціональності готового виробу (системи). Така модель ЖЦ характеризується багаторазовими ітераціями набору елементарних процесів розробки й управління ризиками з метою активного скорочення останніх (Boehm, 1986; 2000).

Спіральна модель ЖЦ має дві відмінні риси. Одна з них полягає в циклічному підході до розроблення для поступового зростання ступеня визначення та реалізації ПЗ під час одночасного зменшення ступеня ризику. Інша - у запровадженні та використанні множини відлікових вузлових точок етапів для забезпечення зобов'язання зацікавлених сторін до допустимих і взаємоприйнятних системних рішень.

Можливий розвиток проєкту по спіральній моделі ЖЦ показано на рисунку 1. Кількість витків, а також розташування і набір видів діяльності в правому нижньому квадранті можуть змінюватися залежно від результатів планування й аналізу ризиків, що проводять на попередніх етапах.

За концепцією спіральної моделі ЖЦ кожна ітерація починається з виділення цілей і планування чергової ітерації, визначення основних альтернатив і обмежень під час ії̈ виконання, їх оцінки, а також оцінки ризиків, що виникають, і визначення способів позбавлення від них, а закінчується оцінкою результатів проведених в ії межах робіт.

Основним новим елементом спіральної моделі ЖЦ є загальна структура дій на кожній ітерації - планування, визначення завдань, обмежень і варіантів рішень, оцінка запропонованих рішень і ризиків, виконання основних робіт ітерації та оцінка результатів. У разі використання цієї моделі ЖЦ закінчений, ПЗ створюється в кілька ітерацій (витків спіралі) методом прототипування. Кожна ітерація $€$ завершеним циклом розробки, що приводить до випуску внутрішньої або зовнішньої версії ПЗ, який вдосконалюється від ітерації до ітерації, щоб стати закінченим продуктом (Boehm, 1986; 2000; http://becmology.ru).

Кожен виток спіралі відповідає створенню фрагмента або версії П3, тобто прототипу, на ньому уточнюються цілі і характеристики проєкту, визначається його якість, плануються роботи на наступному витку спіралі. На кожній ітерації поглиблюються і послідовно конкретизуються деталі проєкту, унаслідок чого обирається обґрунтований варіант, який доводиться до остаточної реалізації. 


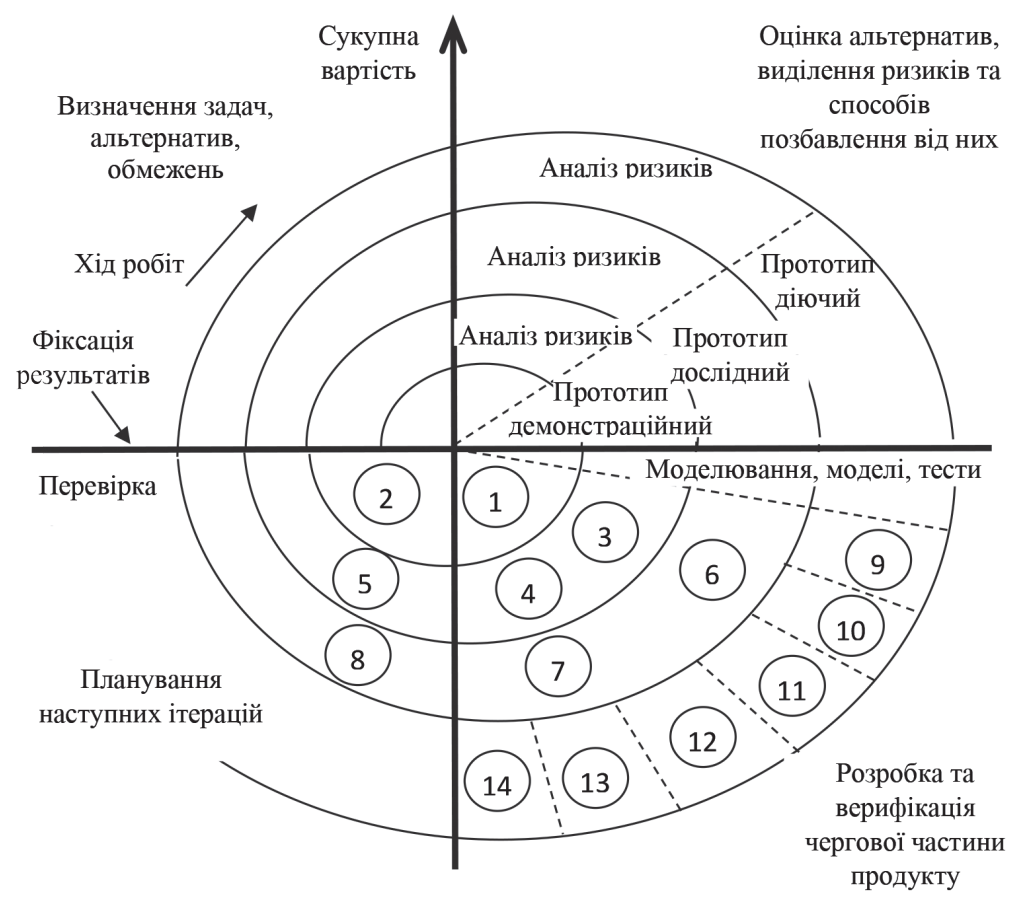

1 - Концепція процесу

2 - План ЖЦ та роботи з вимогами

3- Вимоги до ПП

4 - Перевірка вимог

5 - План розробляння

6 - Проєктування ПП

7 - Верифікація та атестація проєкту
8 - План інтегрування та тестування

9 - Проєктування модулів

10 - Кодування

11 - Тестування модулів

12 - Інтеграція та тестування системи

13 - Приймальне тестування

14 - Розгортання

Прототип демонстраційний - дієве ПЗ, що виконує частину функцій, демонструє правильність підходу.

Прототип дослідний - дієве ПЗ, що виконує більшість функцій, але ще не повністю перевірене.

Прототип дієвий - ПЗ, що надійно виконує функції в реальних умовах.

\section{Рис. 1. Спіральна модель ЖЦ}

Під час використання спіральної моделі ЖЦ (виконання відповідного їй проєкту) виявлено такі переваги:

а) наявність дій з аналізу ризиків, що забезпечує їх скорочення і завчасне визначення непереборних ризиків;

б) забезпечення розбиття великого потенційного обсягу робіт з розробки Пз на невеликі частини;

в) першочерговість реалізації вирішальних функцій з високим ступенем ризику, що дозволяє за необхідності зупинити роботи над проєктом на ранніх циклах моделі та зменшити витрати; 
г) можливість гнучкого проєктування, що базується на перевагах каскадної моделі у разі одночасного дозволу ітерацій;

д) реалізація переваг інкрементної моделі (випуск інкрементів, скорочення графіка робіт, незмінюваність ресурсів за умови поступового зростання системи);

е) реалізація зв'язку з користувачем з високою частотою і на ранніх етапах моделі, що забезпечує створення необхідного продукту високої якості;

ж) можливість оцінки ПЗ користувачем на ранніх етапах за рахунок використання прототипування;

i) можливість користувачів брати участь у плануванні, аналізі ризиків, проєктуванні, розробці, виконанні оціночних дій;

к) удосконалення адміністративного управління за допомогою процесу розробки, витрат, дотримання графіка і кадрового забезпечення, що досягається через виконання аналізу (огляду) в кінці кожної ітерації;

л) підвищення продуктивності за рахунок використання придатних для повторного використання результатів;

м) підвищення ймовірності передбачуваної поведінки системи за допомогою уточнення поставлених цілей;

н) відсутність необхідності в попередньому розподілі всіх потрібних для виконання проєкту фінансових ресурсів;

п) можливість регулярної оцінки сукупних витрат, що призводить до їх загального скорочення.

Головне завдання, виконання якого забезпечує спіральна модель ЖЦ, - якомога швидше показати замовнику працездатне П3, активізуючи процес уточнення і доповнення вимог.

Застосування спіральної моделі Жц доцільне в такому разі:

- під час розробки проєктів, що використовують нові технології;

- під час розробки проєктів, в яких необхідно протестувати базові концепції;

- під час розробки проєктів, в яких необхідна демонстрація якості та версій системи або продукту через короткий проміжок часу;

- під час розробки проєктів, пов'язаних із середнім і високим ступенем ризику;

- під час розробки проєктів з очікуваними істотними змінами або доповненнями вимог;

- під час розробки проєктів у разі, якщо користувач не впевнений у своїх потребах;

- під час розробки великих проєктів;

- для виконання довгострокових проєктів;

- під час розробки проєктів із занадто складними вимогами;

- під час розробки нової серії продуктів або систем;

- під час розробки проєктів в умовах відсутності можливостей завчасного виділення всіх необхідних для виконання проєкту коштів;

- під час розробки систем, які потребують великого обсягу обчислень;

- під час виконання бізнес-проєктів, проєктів у галузі аерокосмічної промисловості, оборони та інжинірингу; 
- під час розробки проєктів, для яких необхідний підрахунок витрат, пов'язаних з оцінкою і зменшенням або усуненням ризиків;

- під час розробки проєктів ворганізації, яка має навички, необхідні для адаптації моделі Жц. Процес адаптації полягає увиключенні процесів, робіт ізавдань, які не застосовуються в умовах конкретного проєкту (ДСТУ ISO/IEC/IEEE 12207:2018, 2018).

Використання спіральної моделі дозволяє здійснювати перехід на наступний етап виконання проєкту, не чекаючи повного завершення поточного - недороблену роботу можна буде виконати на наступній ітерації. Головне завдання кожної ітерації - якомога швидше створити працездатний продукт, який можна показати користувачам системи. Отже, істотно спрощується процес внесення уточнень і доповнень до проєкту. Спіральна модель позбавляє замовника і розробника від необхідності повного і точного формулювання вимог до системи на початковій стадії, оскільки вони уточнюються на кожному витку спіралі (ітерації або етапі розробки версії системи). Так, постійно поглиблюються та конкретизуються деталі проєкту і обирається обґрунтований варіант, який доводять до реалізації (ДСТУ ISO/IEC TR 15271:2010, 2010; Larman, 2003; Алексєєв та Терещенко, 2003).

Отже, з огляду на суттєві переваги спіральної моделі ЖЦ, з урахуванням можливих ризиків ії застосування у разі виконання невідповідного їй проєкту розроблення ПЗ доцільно застосувати підходи міжнародних стандартів (ДСТУ ISO/IEC TR 15271:2010, 2010; ДСТУ ISO/IEC/IEEE 12207:2018, 2018), зокрема використати спіральну модель Жц.

Усвідомлення життєвого циклу ПЗ за наведеною моделлю не тільки спрощує первинне завдання з розроблення або придбання ПЗ - написання технічного завдання (Т3) та складання плану робіт, а й дозволяє спланувати довгострокову перспективу розвитку проєкту - кількісне масштабування та якісне нарощування функціоналу, версійність програмного забезпечення.

Окрема частина ТЗ на програмно-технологічні рішення у секторі спадщини завжди пов'язана з вебрепрезентацією ресурсів, цифрових колекцій, сервісів, їх інтеграцією у сайти установ, портальні рішення та глобальні ресурси і системи.

Незважаючи на наявний багаторічний практичний досвід інституцій культури з розроблення вебсайтів, усвідомленого і детально відпрацьованого підходу до них досі немає. Досвід розробки сайтів непрофесійними розробниками сьогодні відбивається на якості цих вебсайтів. Через відсутність сталого ринку ПЗ в секторі спадщини немає професійних пропозицій від розробників.

Тому, долучаючись до розроблення або модернізації сайту, слід застосовувати насамперед наукові підходи до передпроєктних досліджень щодо розроблення інформаційної структури, контенту та дизайну, вебінтерфейсів ресурсів установи пам'яті: вивчати світовий досвід і приклади вебрішень провідних національних та міжнародних інституцій та проєктів.

По-друге, варто застосовувати уніфіковані рекомендації з сайтобудування, які з'являються в глобальних світових проєктах. Зокрема, слід звернути увагу на «класичні» рекомендації, викладені у керівництві «Принципи якості вебсайтів сфери культури» (http://www.minervaeurope.org), які розроблено робочою гру- 
пою проєкту «Minerva» п'ятої рамкової програми ЄС. У керівництві наведено матрицю з 9-ох стадій життєвого циклу вебсайту та 10-ти принципів якості, найбільш важливих для кожної стадії (Рис. 2) (http://www.minervaeurope.org). Слід додати, що застосування наведеної матриці якості стадій життєвого циклу вебсайту до спіральної моделі жЦ ПЗ дозволяє сформувати чітке уявлення і спланувати будьякий цифровий інформаційно-ресурсний проєкт установи пам'яті.

Третя рекомендація - звертати увагу на корисні загальні технічні та інтерфейсні вимоги, які сьогодні відпрацьовуються вже досвідченими фахівцями для державних сайтів і цифрових сервісів тощо; аналізувати такі вебсайти як приклади.

\begin{tabular}{|c|c|c|c|c|c|c|c|c|c|}
\hline & 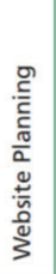 & 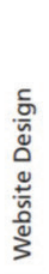 & 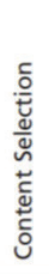 & 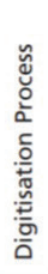 & 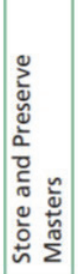 & 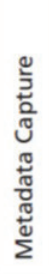 & 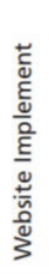 & 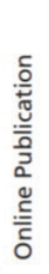 & 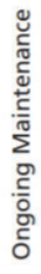 \\
\hline Transparent & 2 & 3 & 1 & 1 & 1 & 1 & 3 & 3 & 2 \\
\hline Effective & 2 & 3 & 3 & 1 & 1 & 2 & 3 & 3 & 3 \\
\hline Maintained & 2 & 1 & 2 & 2 & 1 & 1 & 1 & 3 & 3 \\
\hline Accessible & 3 & 3 & 1 & 2 & 1 & 1 & 3 & 1 & 1 \\
\hline User-centred & 2 & 3 & 1 & 1 & 1 & 1 & 3 & 1 & 2 \\
\hline Responsive & 2 & 2 & 3 & 1 & 1 & 1 & 2 & 3 & 3 \\
\hline Multi-lingual & 3 & 3 & 2 & 2 & 1 & 1 & 3 & 2 & 1 \\
\hline Interoperable & 3 & 3 & 1 & 3 & 2 & 3 & 3 & 2 & 2 \\
\hline Managed & 1 & 1 & 3 & 1 & 2 & 1 & 1 & 1 & 1 \\
\hline Preserved & 1 & 1 & 2 & 3 & 3 & 3 & 1 & 1 & 2 \\
\hline
\end{tabular}

Принципи якості (по вертикалі):

Порочність

Ефективність

Підтримка

Доступність

Орієнтація на користувача

Реактивність

Багатомовність

Сумісність

Керованість

Збереженість
Стадії життєвого циклу вебсайту (по горизонталі):

Планування

Організація

Відбір змісту

Оцифровування

Зберігання і збереженість матеріалів

збирання метаданих

Упровадження

Публікування в онлайн

Підтримка

Puc. 2. Матриця визначення якості на різних стадіях життєвого циклу вебсайту за пріоритетами вагою від 1 до 3 


\section{Висновки}

1. Відстеження тенденцій і практик розвитку IT в секторі культурної спадщини, усвідомлення реальних умов існування та розвитку ринку програмного забезпечення, а також свідоме застосування саме спіральної моделі життєвого циклу програмного забезпечення до проєктування й планування програмно-технологічних рішень надає замовникам ПЗ (у секторі культурної спадщини) можливість ефективно впливати на розроблення ПЗ від формування технічного завдання до впровадження. Зокрема це дозволить усвідомлено планувати етапи і бюджет розроблення програмного забезпечення, знижувати власні ризики, що зазвичай супроводжують цей процес. Також це дозволить ефективно впливати на технологічний розвиток установи пам'яті та підтримувати ії діяльність, ресурси і сервіси на сучасному рівні IT, планувати заходи з упровадження саме нових технологій нових не тільки для поточного стану IT в установі, а й нових відповідно до світових практик, тенденцій і трендів.

2. Наведена модель життєвого циклу програмного забезпечення дозволить IT розробникам та дистриб'юторам програмно-технологічних рішень, IT-інтеграторам, а також студентам, що навчаються програмуванню, ефективно (послідовно, обґрунтовано та прозоро) розробляти і пропонувати, зрозуміло надавати замовнику окремі рішення й комплексні ІТ-проєкти відповідно до його (замовника) потреб (саме в секторі культурної спадщини).

3. Застосування наведених у публікації результатів досліджень щодо життєвого циклу програмного забезпечення та рекомендацій щодо розроблення сайтів закладів культури й інтерфейсів інформаційних систем і цифрових колекцій сприятиме підвищенню якості ресурсів і сервісів у вітчизняному секторі культурної спадщини, доступності цифрових ресурсів і сервісів широкої аудиторії користувачів, що у свою чергу сприятиме підвищенню рівня інформаційного розвитку суспільства в цілому.

4. ІТ розвиток вітчизняного сектору спадщини, орієнтований на провідні світові практики, стандарти, тренди та програми розвитку, сприятиме цифровому розвитку та інтеграції ресурсів вітчизняних установ пам'яті в глобальні інформаційні системи та інтегровані цифрові ресурси, збільшення долі вітчизняного контенту у світовому історико-культурному ресурсі та формуванню позитивного іміджу України як частини європейської і світової історії та сучасного IT-суб'єкта у секторі культурної спадщини.

\section{СПИСОК ПОСИЛАНЬ}

Алексєєв, В.С. та Терещенко, В.С., 2003. Розвиток спіральної моделі життєвого циклу програмних систем. Проблеми програмування, [online] 4, с.34-42. Доступно: <http://dspace. nbuv.gov.ua/bitstream/handle/123456789/1335/03-Tereshchenko.pdf?sequence=1> [Дата звернення 30 серпня 2019]. 
Баркова, О. та Кульчицький, І., 2019. Європейський та український досвід використання цифрових технологій у сфері культури. Аналітичний огляд та пропозиції на основі матеріалів дискусійного форуму. В: Синергія мистецтва, культури та технологій як джерело креативності та інновачій. Львів, 14 червня 2019 р. Львів [online] Доступно: <https:// www.dropbox.com/s/z94r0iq165hcdgl/Barkova\%20Kulchytskyy\%20Kultura\%20vs\%20 Technology\%20Forum\%20materials\%20.pdf?dl=0> [Дата звернення 30 серпня 2019].

Бахтизин, В.В. и Глухова, Л.А., 2006. Стандартизация и сертификация программного обеспечения. Минск: БГУИР. [online] Доступно: <http://libeldoc.bsuir.by/ bitstream/123456789/742/1/Бахтизин,\%20В.\%20В.\%20Стандартизация_и_сертификация_ програм_обеспечения.pdf> [Дата обращеня 3 сентября].

ДСТУ ISO/IEC TR 15271:2010 (ISO/IEC TR 15271:1998, IDT), 2013. Інформаційні технології. Настанови щодо застосування ISO/IEC 12207 (Процеси життєвого циклу програмного забезпечення). Київ: Держспоживстандарт України.

ДСТУ ISO/IEC/IEEE 12207:2018 (ISO/IEC/IEEE 12207:2017, IDT), 2018. Інженерія систем і програмного забезпечення. Процеси життєвого циклу програмного забезпечення.

Нужно ли заказчику понимание проблем разработки ПО? Бэкмология. Бизнес, экономика, менеджмент, организация. [online] Доступно: <http://becmology.ru/blog/4c/soft_ dev01.htm> [Дата обращения 3 сентября 2019].

Про внесення змін до деяких постанов Кабінету Міністрів України щодо функціонування офріційних веб-сайтів органів виконавчої влади. Постанова від 12 червня 2019 р. № 493. Київ. [online] Доступно: <https://zakon.rada.gov.ua/laws/show/493-2019-\%D0\%BF> [Дата звернення 30 серпня 2019].

Про затвердження Вимог до програмних продуктів, які використовуються на фондовому ринку, та програмного забезпечення автоматизованих, інформачійних та інформаційно-телекомунікаційних систем, призначених для здійснення професійноі діяльності на фондовому ринку, депозитарної діяльності Центрального депозитарію цінних паперів. Рішення Національної комісії з цінних паперів та фондового ринку 02.10.2012 № 1342. Київ. [online] Доступно: <https://zakon.rada.gov.ua/laws/show/z176012/ed20181214/sp:max15\#n30> [Дата звернення 30 серпня 2019].

Чумакова, Т.Я. та Цыганенко, С.М., 2009. Международные стандарты и жизненные циклы программного обеспечения. Математичні машини і системи, [online] 3, c.144-150. Доступно: <http://www.immsp.kiev.ua/publications/articles/2009/2009_3/ Chumakova_03_2009.pdf> [Дата звернення 30 серпня 2019].

Barkova, O., 2018. Digitized Heritage Events - from Studying to Actions or the Ukrainian Digital Movement. Uncommon Culture. Cultural Heritage, Real Virtual, 7, 1/2 (13/14), pp.186-192.

Boehm, B., 1986. A Spiral Model of Software Development and Enhancement. ACM SIGSOFT ACM SIGSOFT Software Engineering Notes. New York: ACM, [online] 11, 4, p.14-24. Available at: <https://docviewer.yandex.ua/?url=http\%3A\%2F\%2Fportal.ou.nl\%2Fdocuments\%2F1149 64\%2F2986739\%2FIM0303_02.pdf\&name=IM0303_02.pdf\&lang=en\&c=56ea6be5cb95\&pa ge=1> [Accessed 3 September 2019].

Boehm, B., 2000. Spiral Development: Experience, Principles and Refinements: Special Report CMU/SEI-2000-SR-008. Pittsburgh: Carnegie Mellon University. [online] Available at: <http:// www.sei.cmu.edu/reports/00sr008.pdf> [Accessed 3 September 2019].

Larman, C. and Basili, V.R., 2003. Iterative and Incremental Development: A Brief History. IEEE Computer: IEEE Computer Society. [online] pp.2-11. Available at: <http://www.craiglarman. com/wiki/downloads/misc/history-of-iterative-larman-and-basili-ieee-computer.pdf> [Accessed 3 September 2019]. 
Quality Principles for Cultural Websites: a Handbook, 2005. Edited by Minerva Working Group 5 Identification of user needs, contents and quality criteria for Cultural Web Applications. [online] Available at: <http://www.minervaeurope.org/publications/qualitycommentary/ qualitycommentary050314final.pdf?fbclid=IwAR1ul5a6a5ucMWdqUITMBOdocYshbJ7Qj06kP HdSQ-hgVIbcoJ7dwG_3iF4 [Accessed 3 September 2019].

\section{REFERENCES}

Aleksieiev, V.S. and Tereshchenko, V.S., 2003. Rozvytok spiralnoi modeli zhyttievoho tsyklu prohramnykh system [Development of a spiral model of a life cycle of software systems]. Problemy prohramuvannia, [online] 4, pp.34-42. Available at: <http://dspace.nbuv.gov.ua/ bitstream/handle/123456789/1335/03-Tereshchenko.pdf?sequence=1 $>$ [Accessed 30 August 2019].

Bakhtizin, V.V. and Glukhova, L.A., 2006. Standartizatciia i sertifikatciia programmnogo obespecheniia [Standardization and Certification of Software]. Minsk: BGUIR. [online] Available at: <http://libeldoc.bsuir.by/bitstream/123456789/742/1/Bakhtizin,\%20V.\%20V.\%20 Standartizatciia_i_sertifikatciia_program_obespecheniia.pdf> [Accessed 3 September 2019]. Barkova, O., 2018. Digitized Heritage Events - from Studying to Actions or the Ukrainian Digital Movement. Uncommon Culture. Cultural Heritage, Real Virtual, 7, 1/2 (13/14), pp.186-192. Barkova, O. and Kulchytskyi, I., 2019. Yevropeiskyi ta ukrainskyi dosvid vykorystannia tsyfrovykh tekhnolohii u sferi kultury. Analitychnyi ohliad ta propozytsii na osnovi materialiv dyskusiinoho forumu [European and Ukrainian experience in the use of digital technologies in the cultural sphere. Analytical review and suggestions based on discussion board material]. In: Synergy of Art, Culture and Technology as a Source of Creativity and Innovation. Lviv, 14 June, 2019. Lviv [online] Available at: <https://www.dropbox.com/s/z94rOiq165hcdgl/Barkova\%20 Kulchytskyy\%20Kultura\%20vs\%20Technology\%20Forum\%20materials\%20.pdf?dl=0> [Accessed 30 August 2019].

Boehm, B., 1986. A Spiral Model of Software Development and Enhancement. ACM SIGSOFT ACM SIGSOFT Software Engineering Notes. New York: ACM, [online] 11, 4, pp.14-24. Available at: <https://docviewer.yandex.ua/?url=http\%3A\%2F\%2Fportal.ou.nl\%2Fdocuments\%2F1149 64\%2F2986739\%2FIM0303_02.pdf\&name=IM0303_02.pdf\&lang=en\&c=56ea6be5cb95\&pa ge $=1>$ [Accessed 3 September 2019].

Boehm, B., 2000. Spiral Development: Experience, Principles and Refinements: Special Report CMU/SEI-2000-SR-008. Pittsburgh: Carnegie Mellon University. [online] Available at: <http:// www.sei.cmu.edu/reports/00sr008.pdf> [Accessed 3 September 2019].

Chumakova, T.la. and Tcyganenko, S.M., 2009. Mezhdunarodnye standarty i zhiznennye tcikly programmnogo obespecheniia [International standards and software life cycles]. Matematychni mashyny i systemy, [online] 3, pp.144-150. Available at: <http://www.immsp. kiev.ua/publications/articles/2009/2009_3/Chumakova_03_2009.pdf> [Accessed 30 August 2019].

DSTU ISO/IEC TR 15271:2010 (ISO/IEC TR 15271:1998, IDT). Informatsiini tekhnolohii. Nastanovy shchodo zastosuvannia ISO/IEC 12207 (Protsesy zhyttievoho tsyklu prohramnoho zabezpechennia) [DSTU ISO / IEC TR 15271: 2010 (ISO / IEC TR 15271: 1998, IDT), 2013. Information technology. Guidelines for the application of ISO / IEC 12207 (Software Lifecycle Processes)]. Kyiv: Derzhspozhyvstandart Ukrainy. 
DSTU ISO/IEC/IEEE 12207:2018 (ISO/IEC/IEEE 12207:2017, IDT) Inzheneriia system i prohramnoho zabezpechennia. Protsesy zhyttievoho tsyklu prohramnoho zabezpechennia [DSTU ISO / IEC / IEEE 12207: 2018 (ISO / IEC / IEEE 12207: 2017, IDT) Systems and Software Engineering. Software Lifecycle Processes].

Larman, C., and Basili, V.R., 2003. Iterative and Incremental Development: A Brief History. IEEE Computer: IEEE Computer Society. [online] pp.2-11. Available at: <http://www.craiglarman. com/wiki/downloads/misc/history-of-iterative-larman-and-basili-ieee-computer.pdf [Accessed 3 September 2019].

Nuzhno li zakazchiku ponimanie problem razrabotki PO? [Does the customer need an understanding of the problems of software development?]. Bekmologiia. Biznes, ekonomika, menedzhment, organizatciia [online] Available at: <http://becmology.ru/blog/4c/soft_dev01. htm> [Accessed 3 September 2019].

Pro vnesennia zmin do deiakykh postanov Kabinetu Ministriv Ukrainy shchodo funktsionuvannia ofitsiinykh veb-saitiv orhaniv vykonavchoi vlady [Amendments to some resolutions of the Cabinet of Ministers of Ukraine on the functioning of official websites of the executive authorities]. Resolution No. 49312 June, 2019. Kyiv [online] Available at: <https://zakon.rada.gov.ua/laws/ show/493-2019-\%D0\%BF> [Accessed 30 August 2019].

Pro zatverdzhennia Vymoh do prohramnykh produktiv, yaki vykorystovuiutsia na fondovomu rynku, ta prohramnoho zabezpechennia avtomatyzovanykh, informatsiinykh ta informatsiinotelekomunikatsiinykh system, pryznachenykh dlia zdiisnennia profesiinoi diialnosti na fondovomu rynku, depozytarnoi diialnosti Tsentralnoho depozytariiu tsinnykh paperiv [On approval of the Requirements for software products used in the stock market and software of automated, information and information-telecommunication systems intended for carrying out professional activity in the stock market, depositary activity of the Central Securities Depository]. Decision of the National Securities and Stock Market Commission 02.10.2012 No 1342, Kyiv. [online] Available at: <https://zakon.rada.gov.ua/laws/show/z1760-12/ed20181214/ sp:max15\#n30> [Accessed 30 August 2019].

Quality Principles for Cultural Websites: a Handbook, 2005. Edited by Minerva Working Group 5 Identification of user needs, contents and quality criteria for Cultural Web Applications. [online] Available at: <http://www.minervaeurope.org/publications/qualitycommentary/ qualitycommentary050314final.pdf?fbclid=IwAR1ul5a6a5ucMWdqUITMBOdocYshbJ7Qj06kP HdSQ-hgVIbcoJ7dwG_3iF4 [Accessed 3 September 2019]. 
UDC 004.239:719

\section{Barkova Olha,}

Senior Researcher, Phd in Technical Sciences,

Deputy Chairman of the Technical Committee for Standardization

TC 144 "Information and documentation",

V. O. Sukhomlinskyi State Scientific and Pedagogical Library of Ukraine, expert of UKF,

Kyiv, Ukraine

olgabarkova@gmail.com

https://orcid.org/0000-0003-4412-1835

\section{Babenko Volodymyr,}

Phd in Technical Sciences, Associate Professor,

Research, Design, and Technological Institute of Micrography,

Kharkiv, Ukraine

kripppon@gmail.com

https://orcid.org/0000-0003-0006-3362

\section{Savych Andriy,}

Junior Researcher, Phd in Technical Sciences, Associate Professor,

Research, Design and Technological Institute of Micrography,

Kharkiv, Ukraine

andysav@rambler.ru

https://orcid.org/0000-0003-0590-9195

\section{MEMORY INSTITUTION'S DIGITIZATION SOFTWARE: ISSUES AND APPROACHES IN THE DOMESTIC HERITAGE SECTOR}

The purpose of the study is to identify the causes and develop recommendations for the development of software for memory institutions in the digitalization of cultural heritage.

Research Methods. Based on empirical research and analysis of the software's state and technology of domestic memory institutions, an overview of approaches to software development in the heritage sector has been made. The analysis of slow implementation of software in domestic memory institutions, which negatively influences the processes of digitalization, in particular the development of information resources and digital collections, electronic accounting of funds, is conducted. The basic approaches to the provision of information productions by software and organization of effective interaction of the software life cycle subjects are defined.

The scientific novelty lies in the effective way of project management of software and technological developments proposed for domestic memory institutions from the formation of technical specifications to implementation. Recommendations are given on ensuring the quality of interfaces and websites of digital resources and online services of memory institutions..

Conclusions. The application of the research results will improve the quality of resources and services in the domestic cultural heritage, the availability of digital resources and services to a wide audience of users. This will contribute to the digital development and integration of national cultural heritage into global information systems, integrated digital resources, 
increase the share of domestic content in the world historical and cultural resource, and create a positive image of Ukraine as part of European and world history and a modern IT subject in the cultural heritage sector.

The material is designed for executives and professionals of memory institutions, students and IT professionals focused on digitalisation of the heritage and the creative industries.

Keywords: memory institutions; cultural heritage; digitization; software product life cycle; software; information technology; digitization.

\section{Удк 004.239:719}

\section{Баркова Ольга,}

старший научный сотрудник, кандидат технических наук, заместитель председателя технического комитета стандартизации TК 144 "Инорормация и документация», Государственная научно-педагогическая библиотека Украины имени В. А. Сухомлинского, эксперт УКФ, Киев, Украина olgabarkova@gmail.com https://orcid.org/0000-0003-4412-1835

\section{Бабенко Владимир,}

кандидат технических наук, доцент, Научно-исследовательский, проектно-конструкторский и технологический институт микрографии, Харьков, Украина kripppon@gmail.com https://orcid.org/0000-0003-0006-3362

\section{Савич Андрей,}

младший научный сотрудник, кандидат технических наук, доцент, Научно-исследовательский, проектно-конструкторский и технологический институт микрографии, Харьков, Украина andysav@rambler.ru https://orcid.org/0000-0003-0590-9195

\section{ПРОГРАММНОЕ ОБЕСПЕЧЕНИЕ ЦИФРОВИЗАЦИИ УЧРЕЖДЕНИЙ ПАМЯТИ: ПРОБЛЕМЫ И ПОДХОДЫ В ОТЕЧЕСТВЕННОМ СЕКТОРЕ НАСЛЕДИЯ}

Целью исследования является разработка рекомендаций по развитию программного обеспечения учреждений памяти на пути цифровизации культурного наследия.

Методы исследования. На основе эмпирических исследований и анализа состояния программно-технологического обеспечения отечественных учреждений памяти осуществлен обзор подходов к разработке программных продуктов в секторе историко-культурного наследия. Проведен анализ медленного внедрения программного обеспечения в отечественных учреждениях памяти, который негативно влияет на процессы цифрови- 
зации, в частности на развитие информационных ресурсов и цифровых коллекций, электронный учет фондов. Определены основные подходы к обеспечению информационных производств программными средствами и организации эффективного взаимодействия субъектов жизненного цикла программного обеспечения.

Научная новизна заключается в предложенном для отечественных учреждений памяти эффективном пути проектного менеджмента программно-технологических разработок от формирования технического задания до внедрения. Даны рекомендации по обеспечению качества интерфейсов и веб-сайтов цифровых ресурсов и онлайн-сервисов учреждений памяти.

Выводы. Применение приведенных результатов исследований будет способствовать повышению качества ресурсов и сервисов в отечественном секторе культурного наследия, доступности цифровых ресурсов и сервисов широкой аудитории пользователей. Это будет способствовать цифровому развитию и интеграции национального культурного наследия в глобальные информационные системы и интегрированные цифровые ресурсы, увеличению доли отечественного контента в мировом историко-культурном ресурсе и формированию положительного имиджа Украины как части европейской и мировой истории и современного IT-субъекта в секторе культурного наследия. Материал рассчитан на руководителей и специалистов учреждений памяти, студентов и IT-специалистов, ориентированных на цифровизацию наследия и креативные индустрии.

Ключевые слова: учреждения памяти; культурное наследие; цифровизация; жизненный цикл программного продукта; программное обеспечение; информационные технологии; оцифровка. 